\begin{tabular}{|c|c|c|c|}
\hline DE & \multirow{3}{*}{$\begin{array}{l}\text { DE GRUYTER } \\
\text { OPEN }\end{array}$} & $\begin{array}{l}\text { HUNGARIAN JOURNAL OF } \\
\text { INDUSTRY AND CHEMISTRY }\end{array}$ & 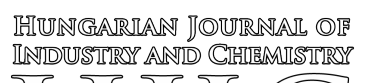 \\
\hline & & Vol. 43(2) pp. 85-89 (2015) & \\
\hline & & $\begin{array}{l}\text { hjic.mk.uni-pannon.hu } \\
\text { DOI: 10.1515/hjic-2015-0014 }\end{array}$ & 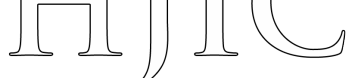 \\
\hline
\end{tabular}

\title{
APPLICATION OF IONIC LIQUIDS IN THE UTILIZATION OF THE AGRICULTURAL WASTES: TOWARDS THE ONE-STEP PRE-TREATMENT AND CELLULOSE HYDROLYSIS
}

\author{
GÁbor Megyeri, ${ }^{1}$ NÁNdor Nemestóthy, ${ }^{1}$ Milan Polakovic,${ }^{2}$ KATAlin BÉlafi-Bakó, ${ }^{1}$ \\ LÁSZLÓ GUBICZA ${ }^{1, *}$ \\ ${ }^{1}$ Membrane Technology and Energetics, Research Institute of Bioengineering, Faculty of \\ Engineering, University of Pannonia, Egyetem u. 10., Veszprém, 8200, HUNGARY \\ ${ }^{2}$ Department of Chemical and Biochemical Engineering, Institute of Chemical and Environmental \\ Engineering, Faculty of Chemical and Food Technology, Slovak University of Technology, \\ Radlinského 9., Bratislava, 81237, SLOVAKIA
}

\begin{abstract}
Cheap, renewable lignocellulosic materials are relevant to the future of biofuel production. Wood and agricultural wastes (e.g. straw, corn stover) provide a raw material source that cannot be used for human consumption, thus biofuels from such sources do not threaten the food supply. The aim of the work was to carry out the pre-treatment and hydrolysis of lignocellulosic material in the same ionic liquid solvent (1-n-butyl-3methyl-imidazolium-chloride, $[\mathrm{Bmim}] \mathrm{Cl})$, using ground wheat straw and a mixture of corn (Zea mays) leaf and stover, as substrates. Our measurements show that it is possible to achieve an acceptable glucose content from the cellulose by applying Cellic $₫$ CTec2 and Cellic $₫$ HTec2 enzyme complexes.
\end{abstract}

Keywords: ionic liquid, enzyme, hydrolysis, glucose, agricultural waste, lignocellulose

\section{Introduction}

Nowadays, lignocellulosic plant biomass is considered as a renewable and cheap natural source of energy for second-generation alcohol production and a source of other platform compounds [1]. The main components of plant biomass are cellulose, hemicellulose, and lignin, which form a quite complex molecular structure [2]. Among these substances, the glucose content of cellulose is desirable, which can be obtained in an enzymatic hydrolysis process. However, it is a difficult process, since cellulose is barely soluble in water [3] and thus various pre-treatment methods are required. Physical, chemical, physic-chemical, and biological pretreatments can be used [4], such as steam explosion [5], dilute and concentrated acids [6], etc. These techniques may liberate certain inhibitory compounds that are not desirable, because they can significantly hinder enzymatic hydrolysis. Some ionic liquids, on the other hand, are able to dissolve cellulose selectively making it accessible to the enzymes while unwanted components are not formed.

Ionic liquids are salts with low melting points [7, 8]. They are considered as green solvents [9] due to their negligible surface tension. A large number of anions and cations are available in countless variations for forming ionic liquids [10]. The asymmetric organic

*Correspondence: gubiczal@almos.uni-pannon.hu cation causes the low melting point, because it reduces the lattice energy in 1-alkyl-3-methyl-imidazolium salts [11].

According to literature examples $[12,13]$, the ionic liquid (IL) formed from 1-butyl-3-methyl-imidazolium chloride salt $([\mathrm{Bmim}] \mathrm{Cl})$ was used to dissolve cellulose. This is the most effective ionic liquid in cellulose pretreatment, but some have found that it could cause the deactivation of the enzymes. Hydrolysis cellulase enzyme complexes can be used including endocellulases, (EC 3.2.1.4), exo-cellulases (EC 3.2.1.91) and cellobiases or $\beta$-glucosidases (EC 3.2.1.21).

The aims of this work were i) to study these two key steps (pre-treatment and enzymatic hydrolysis) using pure cellulose, ii) to decide if it is possible to carry out the two steps in the same IL solvent, and iii) to study the processes by using real agricultural waste materials.

\section{Materials and Methods}

The ionic liquid 1-butyl-3-methyl-imidazolium chloride $([\mathrm{Bmim}] \mathrm{Cl})$ was provided by Io-Li-Tec (Heilbronn, Germany). The enzymes Celluclast 1.5L, Cellic HTec2, and Cellic CTec2 were supplied by Novozymes (Bagsvaerd, Denmark). A description of the enzyme (mixtures) can be found on the websites of the producers as in the case of the chemicals. Cellic CTec2 is a brown liquid with a density of $1.15 \mathrm{~g} \mathrm{~cm}^{-3}$ and a slightly fermented odour that contains cellulase (IUB: 


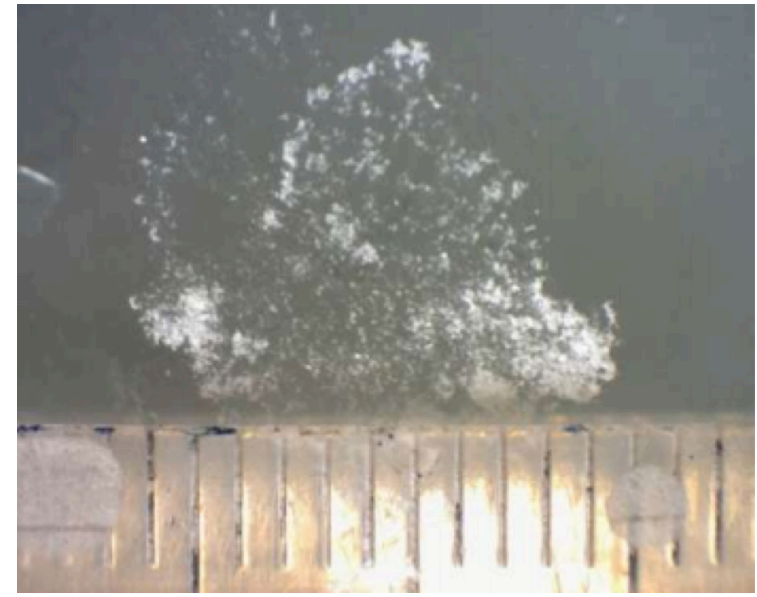

Figure 1. Cellulose in IL before pre-treatment (scale in $\mathrm{mm}$ is shown below the picture)

3.2.1.4) and xylanase. Cellic HTec2 is a yellow liquid with a density of $1.09 \mathrm{~g} \mathrm{~cm}^{-3}$ and lightly fermented odour that contains xilanase (endo-1,4 derivative, IUB: 3.2.1.8). The optimal temperature and $\mathrm{pH}$ for both enzymes are $45-50{ }^{\circ} \mathrm{C}$ and 5.0-5.5, respectively.

The enzymatic reaction was followed by measuring either the glucose content using a GOD glucose kit (Sigma-Aldrich, Budapest, Hungary) or the reducing sugar concentration by the ortho-toluidine (Sigma-Aldrich) spectrophotometric method (HackLange DR 3800 spectrophotometer). Sodium acetate buffer $(\mathrm{pH}=5)$ was used in the hydrolysis experiments with a mixture of acetic acid from Scharlau (Debrecen, Hungary) and $\mathrm{NaOH}$ from Spektrum 3D (Debrecen, Hungary).

Purified cellulose powder (Macherey-Nagel, Düren, Germany), grounded corn leaf and stover (CLS), and wheat straw from local (Veszprém) farmers were used as substrates. The ash contents of the CLS and wheat straw were $7.7 \%$ and $7.3 \%$, respectively, while the maximum obtained reducing sugar yield $\left(\mathrm{RD}_{\max }\right)$ was $44.9 \%$ and $29.6 \%$ in the cases of CLS and wheat straw, respectively.

For the pre-treatment, a specified amount of lignocellulosic substance was dissolved in $0.5 \mathrm{~g}$ of ionic liquid in a glass reactor then mixed slowly $(50 \mathrm{rpm})$ for 10 minutes in a $100{ }^{\circ} \mathrm{C}$ oil bath. Afterwards some buffer and $0.015 \mathrm{~cm}^{-3}$ enzyme preparation were added to the mixture. Then hydrolysis was carried out for 2 hours in a $50{ }^{\circ} \mathrm{C}$ water bath with vigorous mixing $(650 \mathrm{rpm})$. When the hydrolysis finished, the samples were centrifuged in Eppendorf tubes. After that the reducing sugar content was measured using ortho-toluidine.

\section{Results and Discussion}

The first set of experiments was carried out using pure cellulose to study the effectiveness of the pre-treatment as well as enzymatic hydrolysis. Then ground corn stover and leaf, and finally wheat straw were used as substrates.

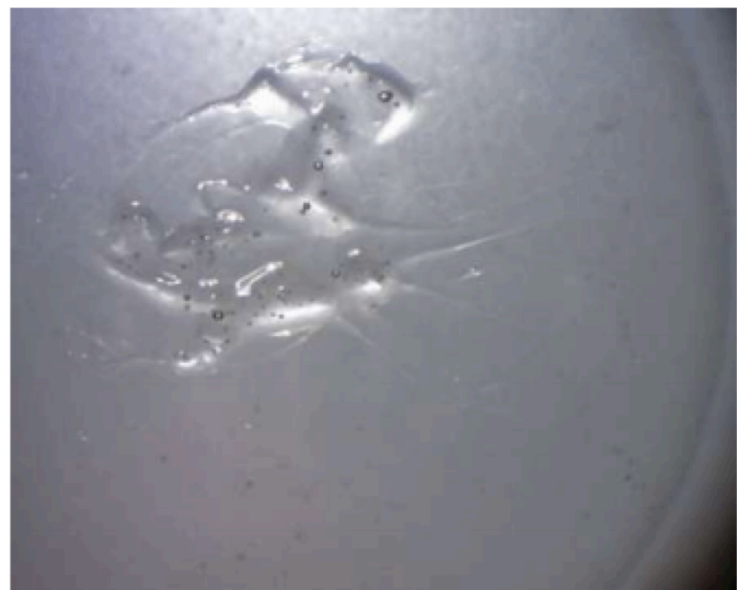

Figure 2. Cellulose in IL after pre-treatment.

Table 1. The glucose content after $2 \mathrm{hr}$ of hydrolysis of pure cellulose.

\begin{tabular}{lc}
\hline \multicolumn{1}{c}{ Enzyme } & Glucose content $(\mathrm{mg})$ \\
\hline Celluclast 1.5 L & 0.7 \\
Cellic HTec2 & 8.4 \\
Cellic CTec2 & 9.6 \\
\hline
\end{tabular}

\subsection{Pure Cellulose}

For the pre-treatment, $25 \mathrm{mg}$ of cellulose $(5 \%)$ was added into $0.5 \mathrm{~cm}^{3}$ of ionic liquid. Following the description of sample preparation in Ref. [14], the highly viscous mixture was incubated at $100{ }^{\circ} \mathrm{C}$ for 10 min, and stirred slowly. Pictures were taken under a microscope to follow changes during the pre-treatment. The pictures of the pure cellulose particles dispersed in IL before and after the $10 \mathrm{~min}$ pre-treatment are shown in Figs.1-2. On the basis of these photos, it seems that a 10 min pre-treatment time is enough for the cellulose to dissolve into the IL.

For the hydrolysis acetate buffer $(\mathrm{pH}=5)$ and enzyme were added to the mixture. On the basis of our preliminary experiments $3.5 \mathrm{~cm}^{3}$ of buffer and $0.015 \mathrm{~cm}^{3}$ of Cellic CTec2 enzyme seemed to be suitable amounts for the reaction. Since the total amount of the mixture is still quite small, the glucose concentration of only the final sample was determined by using the GOD glucose kit. A reaction time of 2 hours was selected on the basis of preliminary measurements. The glucose content was measured in the reaction mixture right after the pre-treatment as well.

No glucose was found in the pre-treated mixture, but $9.6 \mathrm{mg}$ of glucose was detected in the reaction mixture after the enzymatic hydrolysis, which corresponds to approximately $35 \%$ conversion. This indicates that the enzyme was able to function in IL inspite of literature data [15-17] suggesting that IL may inhibit enzymatic function. Thus, our experiment confirmed that it was possible to carry out the pretreatment and enzymatic hydrolysis in the same IL without needing to separate IL from the reaction mixture before the degradation of cellulose. 
Table 2. The amount of reducing sugar ( $\mathrm{mg})$ in the various samples.

\begin{tabular}{ccc}
\hline $\begin{array}{c}\text { Amount of } \\
\text { buffer }\left(\mathrm{cm}^{3}\right)\end{array}$ & $\begin{array}{c}\text { Cellic } \\
\text { HTec2 }\end{array}$ & $\begin{array}{c}\text { Cellic } \\
\text { CTec2 }\end{array}$ \\
\hline 1.0 & 7.16 & 9.36 \\
3.5 & 33.10 & 64.48 \\
7.0 & 32.84 & 76.19 \\
\hline
\end{tabular}

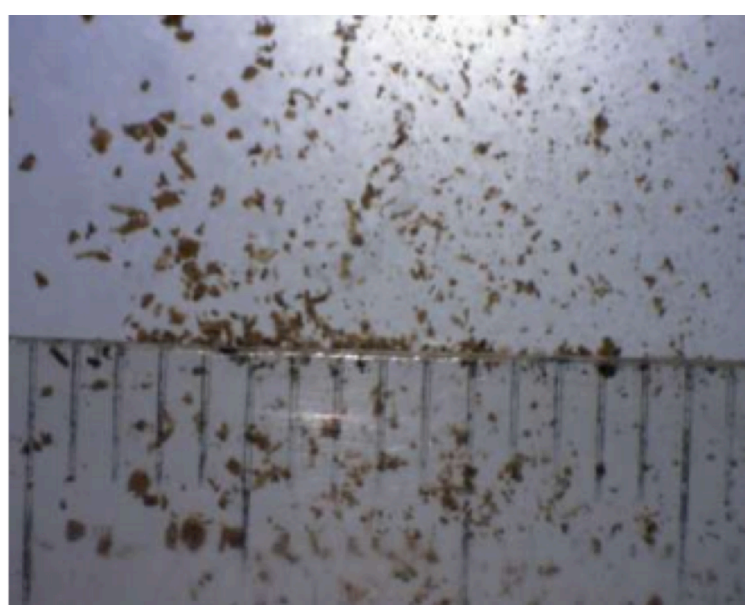

Figure 3. Corn leaf and stover in IL before pretreatment (scale in $\mathrm{mm}$ is shown below the picture).

As follow-up measurements, similar conditions were applied, but the other two enzymes were employed. The glucose content was determined by using the simpler ortho-toluidine reducing sugar method rather than the expensive GOD glucose kit. The results are shown in Table 1.

It can be seen from Table 1 that the Celluclast $1.5 \mathrm{~L}$ enzyme was practically ineffective, while the performance of Cellic CTec2 was similar to the Cellic HTec2 enzyme. Hence, it was decided to use the two Cellic enzymes in our further experiments.

In the next set of measurements, a higher substrate concentration of at least $20 \%$ was applied, although, according to the literature [10], the solubility of cellulose in a similar IL is only 5\%. However, in industry it is not practical to use excessively diluted cellulose solutions. Cellulose of $0.1 \mathrm{~g}$ was added to 0.5 $\mathrm{cm}^{3}$ of IL $(20 \%)$ and the mixture was treated as described above. The higher initial substrate concentration caused difficulties in stirring the mixture. Its viscosity was extremely high and the texture was rather tacky. Elevated stirring was necessary for complete mixing.

After the pre-treatment, the mixtures were treated using buffers and enzymes for the hydrolysis. Firstly, the same conditions were applied as earlier, then the amount of buffer was varied from 1 to $7 \mathrm{~cm}^{3}$. The corresponding results are shown in Table 2.

On the basis of data in Table 2, it was concluded that $1 \mathrm{~cm}^{3}$ of buffer seems to be insufficient for the hydrolysis. A larger buffer amount, however, does not necessarily result in a higher conversion rate; rather it dilutes the samples considerably. Therefore the $3.5 \mathrm{~cm}^{3}$
Table 3. Amount of reducing sugar (mg) in the corn leaf and stover samples.

\begin{tabular}{ccc}
\hline $\begin{array}{c}\text { Amount of } \\
\text { substrate }(\mathrm{mg})\end{array}$ & $\begin{array}{c}\text { Cellic } \\
\text { HTec2 }\end{array}$ & $\begin{array}{c}\text { Cellic } \\
\text { CTec2 }\end{array}$ \\
\hline 0.075 & 6.99 & 10.06 \\
0.100 & 13.82 & 11.61 \\
0.125 & 9.11 & 11.14 \\
\hline
\end{tabular}

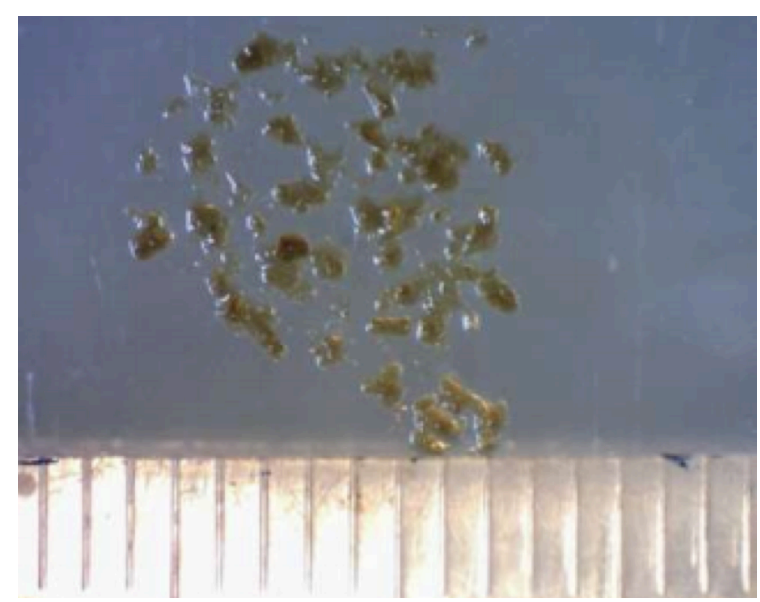

Figure 4. Corn leaf and stover in IL after pretreatment (scale in $\mathrm{mm}$ is shown below the picture).

buffer amount was used in further experiments, which corresponds to a 1:7 ratio of IL solution to buffer. This ratio is similar to the literature data found beneficial for the hydrolysis [17].

The conversion rates of the hydrolysis seem quite high especially in the case of the Cellic CTec 2 enzyme (64.5-76.2\%), but these results can be attributed to the usage of pure cellulose and the higher activity enzymes developed lately.

\subsection{Corn Leaf and Stover}

After the successful experiments using the model substrate: pure cellulose, measurements using ground corn leaf and stover were carried out applying the conditions found suitable earlier: $0.5 \mathrm{~cm}^{3} \mathrm{IL}, 100{ }^{\circ} \mathrm{C}$, and $10 \mathrm{~min}$ pre-treatment time. The initial amounts of the substrate were chosen to be $0.750,0.100$, and $0.125 \mathrm{~g}$ corresponding to 15,20 , and $25 \%$, respectively. The process was followed again by taking pictures under a microscope (Figs.3-4).

The higher initial substrate concentration $(25 \%)$ also caused difficulties in stirring the mixture, but finally the increased stirring applied was enough to achieve complete mixing. It seems, however, that $25 \%$ of substrate poses a physical limit for the process. The pictures proved that the biomass dissolved in the IL during the pre-treatment.

Enzymatic hydrolysis was carried out in the pretreated CLS by adding buffer $\left(3.5 \mathrm{~cm}^{3}\right)$ and either enzymes Cellic CTec2 or Cellic HTec2 $\left(0.015 \mathrm{~cm}^{3}\right)$. After the degradation ( 2 hours of reaction time) sufficiently high amounts of glucose were found in the 
Table 4. Amount of reducing sugar (mg) in the hydrolysed wheat straw samples.

\begin{tabular}{rc}
\hline Enzyme & Amount of reducing sugar $(\mathrm{mg})$ \\
\hline Cellic HTec2 & 7.07 \\
Cellic CTec2 & 8.89 \\
\hline
\end{tabular}

mixture (Table 3), though these values are lower than the ones in the case of pure cellulose.

From the data in Table 3, it can be seen that both enzymes were able to degrade the cellulose content of the biomass, and a quite high amount of glucose was produced. It seems that the differences between the glucose concentrations obtained are not too high, which means that we are approaching the substrate saturation limit, where increased substrate content does not result in a higher amount of glucose production.

The conversion data obtained in the range of 7.2 $14 \%$ indicate that the cellulose content of this biomass is rather difficult for the enzyme to access, thus the hydrolysis is less effective than in the case of pure cellulose. The hydrolytic effectiveness of the enzyme Cellic CTec2 was similar to that of Cellic HTec2.

\subsection{Wheat Straw}

In the final set of experiments, wheat straw was ground and processed in a similar way to other sources used as a substrate in the experiments by applying similar conditions as mentioned earlier. The initial substrate concentration was $25 \%$, which means that $0.125 \mathrm{~g}$ of wheat straw was added to $0.5 \mathrm{~cm}^{3}$ of IL. The results are summarized in Table 4. It can be seen that it is possible to carry out the bioconversion processes using wheat straw as a substrate, but the conversion rate is even lower than for in the case of CLS.

\section{Conclusion}

It can be stated that the pre-treatment and enzymatic hydrolysis of the cellulose content of various types of plant biomass can be carried out using the same ionic liquid, 1-butyl-3-methyl-imidazolium-chloride. Our experiments have proven that acceptable conversion rates could be achieved. Thus, this technique is considered as a chemically feasible approach for the utilisation of the cellulose content of agricultural waste materials for energetic and other purposes.

\section{Acknowledgement}

This work was supported by the projects TÁMOP4.2.2.B-15/1/KONV-2015-0004 and SlovakianHungarian cooperation SK-HU-2013-0008.

\section{REFERENCES}

[1] Abels, C.; Thimm, K.; Wulfhorst, H.; Spiess, A.C.; Wessling, M.: Membrane-based recovery of glucose from enzymatic hydrolysis of ionic liquid pretreated cellulose, Biores. Technol., 2013, 149, 58-64 DOI: 10.1016/j.biortech.2013.09.012

[2] Ha, S.H.; Mai, N.L.; An, G.; Koo, Y.M.: Microwave-assisted pre-treatment of cellulose in ionic liquid for accelerated enzymatic hydrolysis, Biores. Technol., 2011, 102(2), 1214-1219 DOI: 10.1016/j.biortech.2010.07.108

[3] Iguchi, M.; Aida, T.M.; Watanabe, M.; Smith, R.L.: Dissolution and recovery of cellulose from 1butyl-3-methylimidazolium chloride in presence of water, Carbohydrate Polymers, 2013, 92(1), 651658 DOI: 10.1016/j.carbpol.2012.09.021

[4] Chandra, R.; Bura, R.; Mabee, W.; Berlin, A.; Pan, X.; Saddler, J.: Substrate pre-treatment: The key to effective enzymatic hydrolysis of lignocellulosic, Adv. Biochem. Engng./Biotechnol., 2007, 108, 6793 DOI: 10.1007/10_2007_064

[5] Van Eylen, D.; Van Dongen, F.; Kabel, M.; De Bont, J.: Corn fiber, cobs and stover: Enzymeaided saccharification and co-fermentation after dilute acid pre-treatment, Biores. Technol., 2011, 102(10), 5995-6004 DOI: 10.1016/j.biortech.2011.02.049

[6] Lozano, P.; Bernal, B.; Jara, A.G.; Belleville, M.P.: Enzymatic membrane reactor for full saccharification of ionic liquid-pretreated microcrystalline cellulose, Biores. Technol., 2014, 151, 159-165 DOI: 10.1016/j.biortech.2013.10.067

[7] Wang, Y.; Radosevich, M.; Hayes, D.; Labbé, N.: Compatible ionic liquid-cellulase system for hydrolysis of lignocellulosic biomass, Biotechnol. Bioengng., 2010, 108(10), 1042-1048 DOI: 10.1002/ bit.23045

[8] Pinkert, A.; Marsh, K.N.; Pang, S.; Strainger, M.P.: Ionic liquids and their interaction with cellulose, Chem. Rev., 2009, 109(12), 6712-6728 DOI: 10.1021/ cr9001947

[9] Zhu, S.; Wu, Y.; Chen, Q.; Yu, Z.; Wang, C.; Jin, S.: Dissolution of cellulose with ionic liquids and its application: A mini-review, Green Chem ., 2006, 84(4), 325-327 DOI: 10.1039/b601395c

[10]Fehér, E.; Major, B.; Bélafi-Bakó, K.; Gubicza, L.: On the background of enhanced stability and reusability of enzymes in ionic liquids, Biochem. Soc. Trans., 2007, 35(6), 1624-1627 DOI: 10.1042/ BST0351624

[11]Łuczak, J.; Hupka, J.; Thöming, J.; Jungnickel C.: Self-organization of imidazolium ionic liquids in aqueous solution, Colloids Surf. A: Physicochem. Engng. Aspects, 2008, 329(3), 125-133 DOI: 10.1016/ j.colsurfa.2008.07.012

[12] Swatloski, R.P.; Spear, S.K.; Holbrey, J.D.; Rogers, R.D.: Dissolution of cellulose with ionic liquids, J. Am. Chem. Soc., 2002, 124(18), 49744975 DOI: $10.1021 / \mathrm{ja} 025790 \mathrm{~m}$ 
[13]Lozano, P.; Bernal, B.; Bernal, J.M.; Pucheault, M.; Vaultier, M.: Stabilizing immobilized cellulase by ionic liquids for saccharification of cellulose solutions in 1-butyl-3-methylimidazolium chloride, Green Chem., 2011, 13(6), 1406-1410 DOI: 10.1039/ c1gc15294g

[14] Auxenfans, T.; Buchoux, S.; Djellab, K.; Avondo, C.; Husson, E.; Sarazin, C.: Mild pre-treatment and enzymatic saccharification of cellulose with recycled ionic liquids towards one-batch process, Carbohydrate Polymers, 2012, 90(2), 805-813 DOI: 10.1016/j.carbpol.2012.05.101
[15] Turner, M.B.; Spear, S.K.; Huddleston, J.G.; Holbrey, J.D.; Rogers, R.D.: Ionic liquid saltinduced inactivation and unfolding of cellulase from Trichoderma reesei, Green Chem., 2003, 5(4), 443-447 DOI: 10.1039/B302570E

[16] Salvador, Â.C.; Santos, M. Da C.; Saraiva, J.A.: Effect of the ionic liquid [bmim]Cl and high pressure on the activity of cellulase, Green Chem., 2010, 12(4), 632-635 DOI: 10.1039/b918879g

[17] Kamiya, N.; Matsushita, Y.; Hanaki, M.; Nakashima, K.; Narita, M.; Goto, M.; Takahashi, $\mathrm{H}$.: Enzymatic in situ saccharification of cellulose in aqueous-ionic liquid media, Biotechnol. Lett., 2008, 30(6), 1037-1040 DOI: 10.1007/s10529-008-9638-0 